\section{Research Note \\ Chironomidae (Diptera) during the winter season at the middle reaches of the Kiso River}

\author{
Shigeo Kondo* and Manabu SASA** \\ * Department of Parasitology, Aichi Medical \\ University, Nagakute-machi, \\ Aichi 480-11, Japan \\ ** Toyama University of International Studies, \\ Oyama-cho, Toyama 930-12, Japan
}

(Received February 10, 1994)

Key words: Chironomidae, winter season, middle reaches, Kiso River.

\begin{abstract}
The chironomid midges emerged during the winter season were investigated by light and emergence traps at the middle reaches of the Kiso River from November 1988 to March 1989. Fourteen genera and 19 species were identified. The most dominant species, Hydrobaenus kondoi Saether 1989, was especially abundant in midwinter.
\end{abstract}

\section{Introduction}

The southern part of the Kiso River, located in central Japan, flows along the borders of Aichi and Gifu Prefectures.

Every winter since 1986, chironomid midge outbreaks have occurred along the left bank at a distance of 27 to $34 \mathrm{~km}$ from the mouth of the river. This phenomenon was recently studied and the ensuing results revealed that the midge outbreaks have been caused by the high population density of Hydrobaenus kondoi during the winter season (Kondo, 1991). However, except for the nuisance midge, $H$. kondoi, little is known about the species composition and prevalence of the

\footnotetext{
* 近藤繁生：愛知医科大学寄生虫学教室 ( $\mathbf{T} 480-11$ 愛知県愛知郡長久手町岩作㕍又 21)

** 佐々 学: 富山国際大学 ( $\mathbf{T} 930-12$ 富山県上新 川郡大山町東黒牧 65-1)
}

chironomid midges at the surveyed area during the winter season.

In order to determine the species composition and abundance of the chironomid population during the winter season, investigation by light and emergence traps was carried out during the period from November 1988 to March 1989.

\section{Study area and methods}

The chironomid midges were collected at the middle reaches of the Kiso River in Bisai City, Aichi Prefecture. The sampling area looks like a man-made lake because of the construction of a large dam located $27 \mathrm{~km}$ upstream from the mouth of the river. The width is $500-700 \mathrm{~m}$, and the mean depth is about $1.0 \mathrm{~m}$. The water of the area is very clear and has a high concentration of dissolved oxygen (9.5-11.4 mg/liter) during the investigation period. The water current is very slow $(0.07-0.10 \mathrm{~m} / \mathrm{sec})$. The temperature ranged from $\min .3 .5^{\circ} \mathrm{C}$ to $\max .13 .2^{\circ} \mathrm{C}$ in the water and from $\min .4 .0^{\circ} \mathrm{C}$ to $\max$. $15.5^{\circ} \mathrm{C}$ in the air during the investigation period. The river bed near the left bank consists mostly of medium- and fine-grain sand.

Chironomid midges were collected monthly by one light trap ( $6 \mathrm{~W}$ black fluorescent lamp) during the period from November 1988 to March 1989 and by four emergence traps $(50 \mathrm{~cm} \times 50 \mathrm{~cm})$ in December 1988 and February 1989. The light trap was set near the left bank at a point $30 \mathrm{~km}$ from the mouth of the river, and lighting was continued overnight. The four emergence traps were set on the shore line located about 30 $\mathrm{km}$ from the mouth of the river. The midges were collected $24 \mathrm{hr}$ after the emergence traps were set in December, and after $48 \mathrm{hr}$ in February.

The samples were preserved in $70 \%$ alcohol until classification and identification were undertaken. The identification of species was based on male morphological characteristics.

\section{Chironomid species collected}

Nineteen species including eight newly 
Table 1 Chironomid midges (male) captured by a light trap at the middle reaches of the Kiso River from November 1988 to March 1989.

\begin{tabular}{|c|c|c|c|c|c|}
\hline \multirow{2}{*}{ Species } & \multicolumn{5}{|c|}{ No. of individuals } \\
\hline & Nov. & Dec. & Jan. & Feb. & Mar. \\
\hline \multicolumn{6}{|l|}{ Orthocladiinae } \\
\hline Corynoneura kisogawa Sasa et Kondo & 1 & 0 & 0 & 0 & 0 \\
\hline Epoicocladius kisofulvus Sasa et Kondo & 0 & 1 & 0 & 0 & 0 \\
\hline Hydrobaenus kisosecundus Sasa et Kondo & 2 & 4 & 0 & 2 & 0 \\
\hline Hydrobaenus kondoi Saether & 138 & 293 & 131 & 2 & 2 \\
\hline Orthocladius frigidus (Zetterstedt) & 0 & 6 & 1 & 0 & 0 \\
\hline Orthocladius glabripennis (Goetghebuer) & 0 & 82 & 1 & 0 & 2 \\
\hline Orthocladius kanii (Tokunaga) & 0 & 0 & 6 & 0 & 1 \\
\hline Orthocladius tamarutilus Sasa & 0 & 0 & 0 & 0 & 1 \\
\hline Parakiefferilla bathophila (Kieffer) & 6 & 0 & 0 & 0 & 0 \\
\hline Psectrocladius yunoquartus Sasa & 0 & 0 & 0 & 0 & 1 \\
\hline Smittia aterrima (Meigen) & 16 & 3 & 0 & 0 & 8 \\
\hline Smittia kisonudianalis Sasa et Kondo & 0 & 0 & 0 & 0 & 1 \\
\hline \multicolumn{6}{|l|}{ Ghironominae } \\
\hline Chironomus nipponensis Tokunaga & 0 & 0 & 0 & 0 & 1 \\
\hline Paracladopelma kisopediformis Sasa et Kondo & 1 & 0 & 0 & 0 & 0 \\
\hline Polypedilum kisonudum Sasa et Kondo & 1 & 0 & 0 & 0 & 0 \\
\hline Stictochironomus histrio (Fabricius) & 0 & 19 & 0 & 0 & 12 \\
\hline Tanytarsus yunosecundus Sasa & 7 & 0 & 0 & 0 & 0 \\
\hline
\end{tabular}

Table 2 Chironomid midges (male) collected by emergence traps at the middle reaches of the Kiso River in December 1988 and February 1989.

\begin{tabular}{lcc}
\hline \multicolumn{1}{c}{ Species } & \multicolumn{2}{c}{ No. of individuals (ind. $/ \mathrm{m}^{2}$ ) } \\
\cline { 2 - 3 } & December & February \\
Orthocladiinae & & 5 \\
Hydrobaenus kisosecundus Sasa et Kondo & 0 & 20 \\
Hydrobaenus kondoi Saether & 10 & 0 \\
Orthocladius tamarutilus Sasa & 2 & 1 \\
Parakiefferilla bathophila (Kieffer) & 0 & 1 \\
Pseudosmittia kisotriangulata Sasa et Kondo & 0 & 39 \\
Chironominae & & 1 \\
Biwatendipes motoharui Tokunaga & 0 & 1 \\
Stictochironomus histrio (Fabricius) & & \\
\hline
\end{tabular}

described species (Saether, 1989; Sasa and Kondo, 1991, 1993) were identified, and the species composition and number of chironomids during the winter season were determined. Differences in number of the dominant species was found in both light and emergence traps.

As for chironomid midges collected by the light trap, twelve genera and 17 species were identified.

The species composition and the number of male midges collected during the 5 months 
are shown in Table 1. The most dominant species, Hydrobaenus kondoi, especially occurred from November to January. The species predominated 50 to $90 \%$ over the others during the winter season. The number of other species was very small except for Orthocladius glabripennis in December, Smittia aterrima in November and March, and Stictochironomus histrio in December and March.

Chironomid midges collected by the emergence traps are shown in Table 2. Six genera and seven species including three newly described species were identified. The most dominant species were $H$. kondoi in December and February, and Biwatendipes motoharui in February. The latter species have just been recorded from Lake Biwa (Tokunaga, 1965; Sasa and Kawai, 1987) and from the middle reaches of the Kiso River (Sasa and Kondo, 1993).

\section{References}

Kondo, S. (1991): Seasonal occurrence of Hydrobaenus kondoi Saether in the middle reaches of the Kiso River. Jpn. J. Sanit. Zool., 42: 211 (in Japanese).

Saether, O. A. (1989): Two new species of Hydrobaenus Fries from Massachusetts, U.S.A., and Japan (Diptera: Chironomidae). Ent. Scand., 20: 55-63.

Sasa, M. and K. Kawai (1987): Studies on the chironomid midges of Lake Biwa (Diptera: Chironomidae). Lake Biwa Stud. Monogr., 3: 1-119.

Sasa, M. and S. Kondo (1991): Studies on the chironomids of the middle reaches of Kiso River, Aichi. Res. Rep. Toyama Pref. Envir. Poll. Res. Center, 1991: 101-104.

Sasa, M. and S. Kondo (1993) : Additional chironomids recorded from the middle reaches of Kiso River. Res. Rep. Toyama Pref. Envir. Poll. Res. Center, 1993: 98-106.

Tokunaga, M. (1965): A new snow midge from Japan. Kontyû, 33: 42-45.

$$
\begin{gathered}
\text { 摘 要 } \\
\text { 木曽川中流域における冬期の } \\
\text { ユスリカ類について }
\end{gathered}
$$

木曾川中流域における冬期のユスリカ類について， 1988年11月から1989年3月にかけて，ライトトラップ とエマージェンストラップで調查した. その結果, 14 属19種が同定された. 最優占種はキソガワフユユスリ カ Hydrobaenus kondoi Saether であった. 